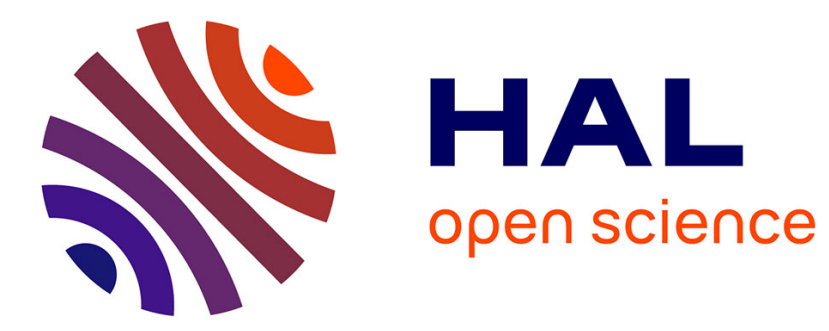

\title{
Captain Haddock's health issues in the adventures of Tintin. Comparison with Tintin's health issues
}

Eric Caumes, Loïc Epelboin, Geraldine Guermonprez, France Leturcq, Peter Clarke

\section{- To cite this version:}

Eric Caumes, Loïc Epelboin, Geraldine Guermonprez, France Leturcq, Peter Clarke. Captain Haddock's health issues in the adventures of Tintin. Comparison with Tintin's health issues. La Presse Médicale, 2016, 45 (7-8), pp.e225 - e232. 10.1016/j.lpm.2016.02.027 . hal-01444927

\section{HAL Id: hal-01444927 https: / hal.sorbonne-universite.fr/hal-01444927}

Submitted on 24 Jan 2017

HAL is a multi-disciplinary open access archive for the deposit and dissemination of scientific research documents, whether they are published or not. The documents may come from teaching and research institutions in France or abroad, or from public or private research centers.
L'archive ouverte pluridisciplinaire HAL, est destinée au dépôt et à la diffusion de documents scientifiques de niveau recherche, publiés ou non, émanant des établissements d'enseignement et de recherche français ou étrangers, des laboratoires publics ou privés. 
Captain Haddock's health issues in the adventures of Tintin. Comparison with Tintin's health issues.

Les problèmes de santé du Capitaine Haddock au cours des aventures de Tintin Comparaisons avec ceux de Tintin

Eric Caumes (1), Loïc Epelboin (1), Geraldine Guermonprez (2), France Leturcq (3), Peter Clarke (4).

1) Department of Infectious and Tropical Diseases. Groupe Hospitalier Pitié-Salpêtrière. 4583 Bld de l’hôpital, 75013 Paris. University Pierre et Marie Curie. Paris, France

2) Fondation Maison des Champs. 18 bis rue des Rasselins. 75020 Paris

3) Laboratoire de Génétique moléculaire, Hôpital Cochin, 75014 Paris UPMC -Inserm UMRS 974 Paris France

4) Manx Text: 118 Woodbourne Road, Douglas, Isle of Man IM2 3BA, British Isles

Correspondence: Eric Caumes. Departement des Maladies Infectieuses et Tropicales. Groupe Hospitalier Pitié-Salpêtrière. 45-83 Bld de l’hôpital, 75013 Paris, France.

Email: eric.caumes@psl.aphp.fr

Tel : 0033142160114

Key Words: Haddock, Tintin, Hergé, Alcohol, Concussion, Trauma. 


\section{Summary}

Background. We currently lack a comprehensive and systematic description of the challenges and health impairments (HI) faced by Captain Haddock over the course of the 15 Tintin adventures in which he appears. Their respective HIs have yet to be compared.

Methods. We evaluated the spectrum of HIs that Haddock sustains in these 15 adventures as well as their causes, consequences, and their relationship to alcohol or travel beyond Belgium. We diagnosed Haddock's HIs according to descriptive terms in the text. We then classified HIs as traumatic and non-traumatic, and distinguished between intentional and unintentional events. We compared the depiction of HIs involving Haddock and Tintin.

Results. We found 225 events leading to 249 HIs, two hospitalisations, and three medical consultations. There was a median of 19 HIs/adventure (range 4-27/adventure) with 193 cases of trauma (77.5\%) and 56 non-traumatic problems (22.5\%). There were 109 cases of concussion (43\% of all HI, 56\% of all trauma). We encountered 12 burns including ten relating to Haddock's tobacco habit. The most common forms of non-traumatic problems were linked to alcoholism (57\%), and specifically drunkenness (37\%). Haddock is diagnosed with cirrhosis early in Tintin's adventures. He significantly decreases his consumption of alcohol after he meets Tintin (58.3\% of HI before vs 10.7\% of HI after; $\mathrm{p}<0.001$; OR 5.4) but not his use of tobacco. He is also susceptible to certain travel-related illnesses such as mosquito bites, ear discomfort, exposure to exotic animals, and perhaps jet lag. Overall, Haddock presents as many HIs (249 vs 244) and trauma (190 vs 193) as Tintin, but suffers significantly more HIs/adventure than Tintin (median 19 vs 8, p =0.03), and the traumas are significantly less severe, LoCs accounting for $23 \%$ of Tintin's traumatic HIs vs $2.5 \%$ for Haddock ( $<<0.001$; OR: 5.1).

Conclusion. Traumatic HIs and concussion are the leading cause of HIs for Tintin and Haddock but are clearly less severe for Haddock. Haddock evolves from alcoholic sea Captain to a country gent who is less addicted to alcohol than he is to tobacco.

\section{Résumé.}


Interet. Une évaluation exhaustive des problèmes de santé (PS) présentés par le capitaine Haddock pendant les 15 aventures de Tintin au cours desquelles il apparaît est nécessaire, pour comparer les PS respectifs des deux héros.

Methodes. Nous avons évalué le spectre des PS que Haddock a présenté au cours de ses 15 Aventures, ainsi que leurs causes, conséquences et lien avec l'alcool ou le voyage en dehors de la Belgique. Les PS ont été diagnostiqués en fonction de leur description dans le texte et le dessin puis classés en distinguant les PS traumatiques des PS non traumatiques. Les causes ont été classées en distinguant les événements intentionnels et non intentionnels. Les PS de Haddock ont été comparés à ceux de Tintin.

Résultats. Nous avons trouvé 225 événements conduisant à 249 PS, deux hospitalisations et trois consultations médicales. Le nombre médian de PS est de 19/aventure (4-27/aventure). Parmi les 249 PS, 193 étaient traumatiques (77.5\%) et 56 non-traumatiques (22.5\%). Les plus fréquents des traumatismes étaient les traumatismes crâniens (56\%), et les plus fréquents des PS non traumatiques étaient les problèmes liés à son alcoolisme (56\%), plus particulièrement ceux engendrée par une ivresse aigue (37\%). Haddock a une probable cirrhose alcoolique. Il a diminué significativement sa consommation d'alcool après sa rencontre avec Tintin, la part des PS liés à l'alcool baissant de 58.3\% à 10.7\% des PS après cette rencontre ( $<<0.001$; OR 5.4). Nous avons trouvé 109 traumatismes crâniens (43\% des problèmes de santé), 12 brûlures (dont 10 liées au tabagisme d'Haddock), et des PS du voyageur (piqûres de moustiques, otalgie barotraumatique, expositions à des animaux exotiques, et troubles du sommeil, évocateurs de décalage horaire). Haddock présente autant de problèmes de santé (249 vs 244) et de traumatismes (190 vs 193) que Tintin. Le nombre médian de PS par aventure est significativement plus élevé pour Haddock (19 vs 8, p = 0.03) mais les traumatismes sont significativement moins sévères, les pertes de connaissances d'origine traumatique représentant $23 \%$ des PS traumatiques chez Tintin vs 2,5 \% chez Haddock $(\mathrm{p}<0.001$; OR: 5.1).

Conclusion. Les traumatismes notamment crâniens sont les principales causes de PS chez Tintin et Haddock mais ils sont moins sévères chez ce dernier qui passe progressivement d'un statut de capitaine de marine, alcoolique avéré, à celui de châtelain, avec un alcoolisme plus mondain, mais est toujours resté un fumeur de pipe invétéré.

\section{Introduction}


The Adventures of Tintin, a series created in 1929 by Hergé (Georges Remi), comprise 23 adventures that appeared between 1930 (Tintin in the Land of the Soviets) and 1976 (Tintin and the Picaros) [1]. Haddock is the second most important character in the series. He is a middle-aged sea wolf who appears in the ninth adventure (figure 1) (The Crab with the Golden Claws), which explains why Haddock features in only 15 of the 23 adventures.

Over the course of their adventures, Tintin and Haddock were exposed to a wide range of health impairments (HIs). Tintin's HIs have been exhaustively evaluated [2]. The HIs of other leading characters, including Snowy the dog, have also been roughly evaluated in seven instances [3-9]. One general study focuses on the medical doctors appearing in Tintin's adventures as well as the citation of diseases, and drugs throughout the text [3]. The six remaining studies focused on the organ corresponding to each author's speciality, respectively neurotraumatology [4], nutrition [5], gastro-enterology-hepatology [6], osteo-articular [7], forensic medicine [8], and psychiatry [8, 9]. Also Haddock’s alcoholism has largely been covered [5, 6, 8, 10, 11]. However the entire spectrum of Captain Haddock's HIs and the different organs' involvements awaits precise examination.

In addition there is no serious comparative analysis of the HIs Haddock and Tintin sustain during their adventures. We merely found opposing conclusions in the only article which attempts to compare Haddock's and Tintin's HIs [7]. Therefore the comparison with Tintin's HIs must also be made.

In Tintin's adventures, we assessed the full spectrum of Haddock's HIs and their causes, consequences, and relationship to alcohol or travel beyond Belgium, his native country, and compared the HIs in the two heroes.

\section{Methods}

We (EC, GG) scrutinised in parallel and blinded manner all 15 completed volumes of Tintin's adventures in which Haddock appeared. Then we assessed all the HIs that arose throughout his stays in Belgium, and during his travels outside Belgium, paying particular attention to the consumption of any alcoholic drink and the potential relationship between alcohol intake, and the occurrence of any HI.

We diagnosed the types of $\mathrm{HI}$ according to the clinical description of Haddock, or his response, in the frames of the strip where each new HI occured, and in the subsequent frames that often amplify the medical nature of the event as described elsewhere for Tintin's HIs [2]. We primarily distinguished traumatic and non-traumatic HIs. We classified HIs as BTwCs (Body Trauma without Consequences other than pain), visible injuries (bumps, scratches and 
burns), concussion, loss of consciousness (LoC), and any other major HIs acknowledged by Haddock, his friends or the authors. Regarding alcohol-related HIs, we distinguished drunkenness, delirium tremens, antabuse effects, and events that occur after he drank alcohol whatever the relationship between alcohol intake and the event.

For each HI we assessed: geographical location (distinguishing between Belgium and other countries or places), cause (distinguishing intentional from unintentional events), and consequences (surgery, hospitalisation, medical consultation). Intentional HIs included attempted homicide, and events provoked by Haddock (termed “Haddock-related”), Haddock’s friends or enemies (termed “Tintin-related”, “friend-related”, and “third partyrelated”, respectively). Unintentional causes of HIs include environment-related events (animal bites, other animal exposure, insect stings, natural disasters, extreme temperatures), transport-related problems, events resulting from Haddock's acts, or following his lapses of judgement or alcohol intake (termed "Haddock-related”), and other unintentional events.

We assessed the number of HIs Haddock had per adventure, those occurring in Belgium and elsewhere, distinguishing between those with alcohol intake and those without. We compared Haddock's and Tintin's HIs. The analysis of Tintin's HIs was made previously using the same method [2].

We summarised categorical variables using percentages, and made comparisons by using the Fisher exact test. We summarised continuous variables using means +/- standard deviations and median and quartiles and compared them using the Student test.

\section{Results}

We found 249 HIs [mean 16.6/adventure (standard deviation +/- 8.1), median 9/adventure; range 4-27/adventure] (Table I). There was at least one HI per adventure. Haddock travelled to four of the world's five inhabited continents, visiting (apart from Belgium) 14 countries plus the Moon. Haddock visited ten real countries and four fictitious ones (Table I) plus space and the Moon.

Of the 249 HIs occurring in the 15 adventures, there were 193 traumas (77.5\%) and 56 nontraumatic problems (22.5\%). The most common forms of traumatic HIs were grade I and II concussions (54\%), and BTwCs (26\%) whereas grade III and IV concussions were rare (2.5\%) (Table II). Overall there were 109 cases of concussion (94 solo concussions, and 15 associated with polytrauma) accounting for $43 \%$ of all HIs. We also found 12 burns including ten relating to Haddock's tobacco habit, which were due to the misuse of matches, cigars or 
pipes. The other traumatic injuries include those caused by animal exposure (bite, concussion, BTwC), insect stings, and other traumas (table II).

The most common forms of non-traumatic HI were alcohol-related (57\%), specifically drunkenness which accounted for 21 HIs (37\%) (Table III). The frequency of HIs occurring under the influence of alcohol was significantly higher in the first adventure compared with the 14 subsequent ones: [14/24 (58.3\%) vs. 24/225 (10.7\%) ; p <0.01 ; OR: 5.4, 95\% CI: 2.312.7). One third of such HIs occured during Haddock's first adventure while the other twothirds occured in 8 of the 11 following adventures. No further episodes related to drunkenness in the three last adventures (table I). The 17 episodes of drunkenness resulted in 23 neuropsychiatric HIs (euphoria/logorrhoea, hallucinations, misbehaviour, sadness, anxiety, sleeping trouble, and aggressiveness). The remaining HIs that occured while Haddock was drunk, were mainly traumatic events induced by his misbehaviour or aggressiveness, which explains why 33 events resulted in 38 HIs.

Beside HIs that occured while Haddock was drunk or had been drinking, other HIs relate to alcohol consumption. Haddock was diagnosed with an alcohol-related liver disease termed either "insuffisance fonctionnelle du foie" (French version) or "poor liver condition”. He also suffered from delirium tremens (DT) in his first adventure when he was a heavy drinker. This DT was associated with hallucinations and aggressiveness which made him strangle Tintin. Haddock was also an unwitting guinea-pig who tested the antabuse effects of a pill invented by Professor Calculus, suffering six related HIs in the final adventure (Tintin in the Picaros). We found 13 LoCs: four grade IV concussions, one grade III concussion, one near-drowning, and seven non-traumatic LoCs (NTLoC) including four g-force events (two rocket landings and two take-offs) and three other NTLoCs (hypoxemia episode in the rocket, heat stroke, and hypnosis).

Haddock was hospitalised twice, initially following an explosion (The Calculus Affair), then for several days following hypnosis by an extra-terrestrial (Flight 714). He doid not undergo surgery. Three times, medical consultation was sought. Initially, he was diagnosed with liver disease early in his fourth adventure (Red Rackham's Treasure) by Dr Daumière (French version) or Dr Leech (English), whose letter to Haddock recommended that he ceased all alcohol intake. The frequency of HIs occurring under the influence of alcohol was significantly higher before this adventure than after it [22/51 (43\%) vs. 16/198 (8\%); p $<0.001$; OR 5.3; 95\% CI 2.5-11.7)]. He was also diagnosed with cardiac arrhythmia after the rocket returns to Earth (Explorers on the Moon). Finally, he was diagnosed with a post- 
traumatic severe twisted ankle (The Castafiore Emeralds) that required his immobilisation in a plaster cast for two weeks.

There are 225 events in all, 24 of them resulting in two HIs. Of these 225 events, 45 (20\%) were intentional and 180 (80\%) unintentional. The commonest events were defined as “Haddock-related", accounting for $50 \%$ of all events. The other causal events by order of frequency relate to Haddock’s friends or enemies, environmental problems, or were transportrelated (Table IV).

There were three types of travel-associated HIs, namely seven animal-related HIs, one case of baro-otalgia (Flight 714), and three insect bite episodes while the fourth episode (a tremendous cellulitis-like reaction to his nose following a bee sting) occured in Belgium (Castafiore Emeralds). All but two of the nine animal-related HIs occured while he was travelling: one bite (by Milama), and seven traumas resulting from blows from crocodile, anaconda, yeti, tapir, monkeys, and electric eel. Haddock also suffered one bite and one blow from a parrot in Belgium, one human bite (Miarka), and one by Snowy. Other animal exposures have not been taken into account as they did not result in any HIs.

Captain Haddock appeared eight adventures after Tintin did, but suffered a total HI number slightly higher than Tintin (249 vs. 244) explaining that the median and mean numbers of HIs per adventure were significantly higher for Haddock (Table V). Furthermore, looking at the chronology of HIs per album for our two heroes the number of HIs per adventure in Tintin decreased while it rose for Haddock (figure 2). Overall traumatic HIs and concussions were as common for Tintin and Haddock but they were less severe for the latter, leading to significantly less traumatic LoCs (table V). In contrast the proportion of HI occurring under the influence of alcohol was much higher for Haddock.

\section{Discussion}

This survey of the 249 HIs Haddock presents during the 15 Tintin adventures in which he appears, reveals that HIs are dominated by trauma similarly to Tintin, but are also related to tobacco smoking and alcohol consumption in contrast to Tintin's abstemious practices. Overall, Haddock presents as many HIs as Tintin does, but over fewer adventures. So Haddock suffers significantly more HIs per adventure than Tintin. As Haddock first appears in 1941 this also explains the sharp decline in Tintin’s HI rate after 1945 (figure 2), something we show but scarcely explain in our previous work [2]. Similarly, the share of traumas remains about the same. However, traumas are significantly less severe because they result in one hospitalisation, and less traumatic LoCs, Grade III and IV concussions accounting for 
23\% of all traumatic HIs for Tintin compared with 2.5\% for Haddock. Another result pointing to less severe events in Haddock is a lower overall number of LoCs (14 vs 46 for Tintin), the absence of surgery (vs two), two hospitalisations (vs six), and one immobilisation for a twisted ankle (like Tintin).

The commonest non-traumatic HIs were alcohol-related. This is unsurprising since it has been shown that the prevalence of alcohol consumption (14.5\%; range 8-75\%) was higher amongst seafarers than among the general population [12]. Note that Haddock’s GP diagnoses him with a liver disease that is certainly alcohol-related as all alcoholic drink is forbidden. This liver disease is termed "poor liver condition" in the English version but "une insuffisance fonctionelle du foie" in the French original. The latter is more precise, pointing to a "liver insufficiency” that is more likely to be cirrhosis. However acute alcoholic hepatitis as also been suggested as a differential diagnosis [6].

Besides suffering from liver failure, Haddock presents other alcohol-related events. He is seen drunk 17 times in nine adventures and there are six sober adventures (Table I). According to Hergé, Tintin exerts a positive influence on Haddock, explaining that Haddock evolves from being an alcoholic freighter captain in the first adventure to a landed gentleman during his fourth adventure who only drinks sporadically in response to specific events (Hergé à Apostrophes, le 5 Janvier 1979. www.ina.fr/video/IO8280434). We thus confirmed Hergé's thoughts as we showed that one-third of the alcohol-related events occur in Haddock's first adventure. Accordingly, the single episode of DT, a sign of severe alcohol addiction, occurs in Haddock's first adventure. We also showed a significant decrease in alcohol-related HIs after Haddock meets Tintin in the first adventure, but also after he is diagnosed with liver disease in the fourth adventure. When Haddock is drunk independently of specific events it mostly occurs while travelling. This is unsurprising as it has been shown among Swiss travellers that the main risk factor for at-risk alcohol consumption during travel abroad was alcohol consumption in Switzerland (OR: 31; 21-45)[13].

The ultimate event relating to alcohol consumption, in the final adventure (Tintin and the Picaros), stems from Professor Calculus's experimental anti-alcohol pill. This is intended to wean Captain Haddock off alcohol. Such an anti-alcohol pill is one of the drugs available for tackling alcoholism $[14,15]$. The antabuse effect is this adventure's masterstroke as it helps General Alcazar's small army to sober up, allowing it to seize power in San Theodoros. We should point out that the experiment takes place without the subject's permission, something inconceivable nowadays. 
Haddock is also diagnosed once with cardiac arrhythmia. It occurs after a severe LoC owing to the combination of hypoxemia (lack of oxygen during the rocket flight's final minutes) and g-force effect (while landing). There is no cardiac follow-up, so it is impossible to ascribe this condition to alcoholic cardiomyopathy or to a transient phenomenon owing to difficulties encountered in the last hours aboard the rocket.

Beside alcoholism, Haddock's other vice is tobacco. Again, it has been shown that the prevalence of tobacco smoking (63\%, range 38-96\%) was higher amongst seafarers than among the general population [12]. Being a heavy pipe-smoker puts Haddock at risk of pulmonary and mouth/throat disease, particularly oral cancer [16]. However there is no indication of these in Haddock. Hergé highlights the consequences of his tobacco habit by allowing Haddock to burn his beard or fingers ten times while lighting or smoking his pipe. In two cases the burns also underline the harmful consequences of combining alcohol consumption and tobacco smoking.

There was no clear relationship between the type of HI and destination. Like Tintin, Haddock presents none of the commonest travel-related health impairments like traveller's diarrhoea, respiratory tract infections, sunburn, seasickness (but he is a sailor), altitude sickness, or fever [2]. However two travel-related HIs can be considered and one discussed. Haddock presents with baro-otalgia which points to ear pressure problems during an abrupt aircraft descent: something well-known among air travellers [17]. He also suffers from exotic animal exposures, insect stings, and animal bites: hardly surprising given that bites and stings are common in travellers [18]. Finally, sleep problems (insomnia, nightmares, and sleepiness) occur in seven cases, including two where they are associated with alcohol consumption (Table III). Although drowsiness may be attributed simply to alcohol, alcohol has been shown to exacerbate jet lag [19].

This study has the same limitations as those in our previous study of Tintin [2]. But we were able to make some comparisons regarding specific problems suspected by rheumatologists [7], gastro-enterologists [6], and nutritionists [5]. However, none of these studies' results is precise enough to allow solid comparison. We considered only the events that lead to an HI. There are also some HIs on which we disagree such as rhynophyma [9]. And there are events we did not consider to result in an HI. For example, some consider that Haddock's regurgitation of two litres of seawater with a fish in it is a sign of megaoesophagus or Meckel's diverticululum [9]. We did not consider such hypothesises as we merely analysed events and their medical consequences, and not possible underlying disease. 
The greater challenge was tackling Haddock’s psychiatric and psychological problems, but these problems have been covered more specifically in the past [8-11]. We did not focus on Haddock's mood, and did not diagnose his mood modifications as HIs but as an inherent characteristic. It was also a challenge to classify alcohol-related HIs as we distinguished HIs relating to continuing alcohol consumption (drunkenness, events occurring while he is drunk), HIs relating to past alcohol consumption (cirrhosis, DT) and the antabuse effect.

To conclude, Haddock is an extraordinary character who often outstrips Tintin. Although his traumas are less severe and result in far fewer hospitalisations and LoCs, the spectrum of HIs is broader, and includes liver cirrhosis, alcoholism, tobacco addiction, and travel-related problems. Haddock's relationship with alcohol illustrates most of the alcoholic's behaviours and health problems linked to alcohol consumption, making Haddock a figure ripe for the study of alcoholism.

\section{Figures:}

\section{Figure 1:}

This is a bronze-made bas-relief on the wall of the Congress Centre (former "Bourse du Commerce”), in Namur, Belgium. It illustrates the first encounter between Tintin and Haddock in "The crab with the golden claws". Credit: Eric Caumes

Ce bas-relief en bronze est scellé sur la facade du palais des congrés (ancienne bourse du commerce) de Namur, Belgique. Il illustre la première rencontre en Tintin et Haddock dans « Le crabe aux pinces d’or ». Credit: Eric Caumes

\section{Figure 2:}

Temporal evolution of the number of health impairments (HIs) per adventure in Tintin and Haddock.

Evolution temporelle du nombre de problèmes de santé par aventure chez Tintin et Haddock

Conflits d'interet: aucun

Thanks to Elisabeth Pierret for her efficient assistance 


\section{References}

1- Wikipedia. The Adventures of Tintin.

https://en.wikipedia.org/wiki/The_Adventures_of_Tintin (accessed on June 5, 2016)

2- Caumes E, Epelboin L, Leturcq F, Kozarsky P, Clarke P. Tintin's travel traumas: Health issues affecting the intrepid globetrotter. Presse Med 2015; 44(6 Pt 1):e203-10.

3- Druez P, Druez A, Druez V. Les nouvelles aventures médicales de Tintin et Milou. La médecine et son univers. Louvain Med 2010 ; 129 : 195-200

4- Castillo M. Tintin and colleagues go to the doctor. Am J Neuroradiol 2011; 32: 1975-6

5- Druez P, Druez A, Druez V. Les nouvelles aventures médicales de Tintin et Milou. Le boire et le manger. Louvain Med. 2010; 129: 228-233

6- Druez P, Druez A, Druez V. Les nouvelles aventures médicales de Tintin et Milou. Quelle place pour la gastro-enterologie. Louvain Med. 2010; 129: 263-266.

7- Huaux JP, Huaux P, Lietaert N. Les aventures médicales de Tintin et Milou. Place de la rhumatologie. Louvain Med. 1986 ; 105 : 589-603 7

8- Bénézech M. Tintin, le traumatisme, la violence et la folie. Regard médicolégal sur l'œuvre d'Hergé. Journal de Médecine Légale Droit Médical 1996 ; 39 : n³

9- Medrano J, Malo P, Uriarte JJ, López AP. Stigma and prejudice in Tintin. BMJ. 2009;339 : b5308.

10- Mozgovine C. De Abdallah à Zorrino ; dictionnaire des noms propres de Tintin. 2eme édition. Casterman. 1992. 284 pages

11- Algoud A. Le Haddock illustré. Edition revue et corrigée. Casterman. 2013. 93 pages 12- Pougnet R, Pougnet L, Loddé B, Canals L, Bell S, Lucas D, Dewitte JD. Consumption of addictive substances in mariners. Int Marit Health. 2014; 65: 199-204.

13- Klunge-de Luze C, de Vallière S, Genton B, Senn N. Observational study on the consumption of recreational drugs and alcohol by Swiss travellers. BMC Public Health 2014; 14: 1199.

14- Jørgensen CH, Pedersen B, Tønnesen $\mathrm{H}$. The efficacy of disulfiram for the treatment of alcohol use disorder. Alcohol Clin Exp Res. 2011; 35: 1749-58.

15- Ipser JC, Wilson D, Akindipe TO, Sager C, Stein DJ. Pharmacotherapy for anxiety and comorbid alcohol use disorders. Cochrane Database Syst Rev. 2015 Jan 20;1: CD007505. 16- Lee YC, Hashibe M. Tobacco, alcohol, and cancer in low and high income countries. Ann Glob Health. 2014; 80: 378-83.

17- Mitchell-Innes A, Young E, Vasiljevic A, Rashid M. Air travellers' awareness of the preventability of otic barotrauma. J Laryngol Otol. 2014; 128: 494-8.

18- Weingarten JA, Collop NA. Air travel: effects of sleep deprivation and jet lag. Chest. 203; 144: 1394-401.

19- Danel T, Libersa C, Touitou Y. The effect of alcohol consumption on the circadian control of human core body temperature is time dependent. Am J Physiol Regul Integr Comp Physiol. 2001; 281: R52-5 


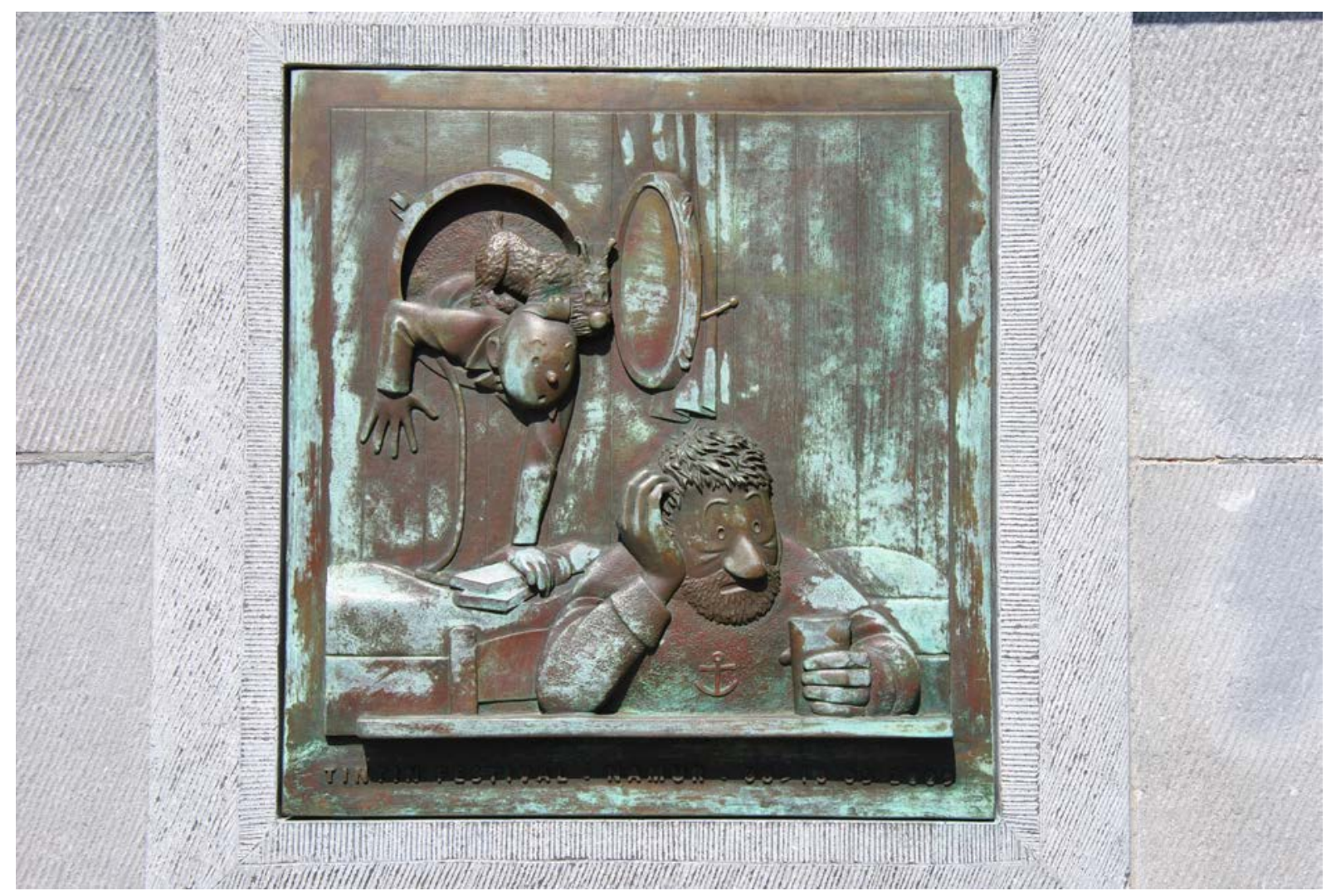

\section{Figure 1:}

This is a bronze-made bas-relief on the wall of the Congress Centre (former "Bourse du Commerce”), in Namur, Belgium. It illustrates the first encounter between Tintin and Haddock in "The crab with the golden claws". Credit: Eric Caumes

Ce bas-relief en bronze est scellé sur la facade du palais des congrés (ancienne bourse du commerce) de Namur, Belgique. Il illustre la première rencontre en Tintin et Haddock dans « Le crabe aux pinces d'or ». Credit: Eric Caumes 


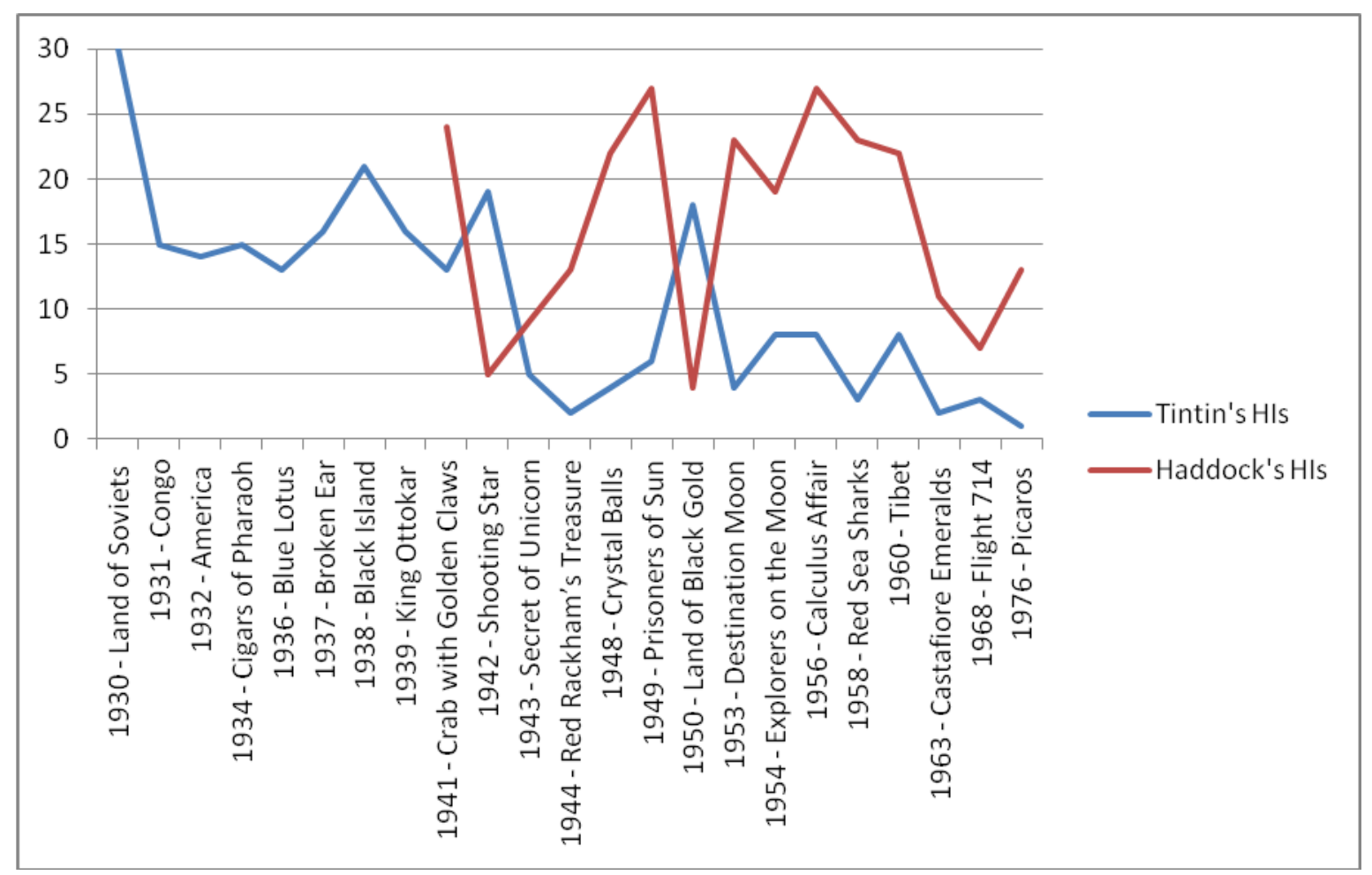

Figure 2: Temporal evolution of the number of health impairments (HIs) per adventure in the two main characters, Tintin and Captain Haddock. Evolution temporelle du nombre de problèmes de santé par aventure chez Tintin et Haddock 
Table I: Countries (Belgium, other countries and places) and events leading to health impairments in Haddock according to the adventure of Tintin (and year)

\begin{tabular}{|c|c|c|c|c|c|c|c|}
\hline Adventure & Year & $\begin{array}{l}\text { Events } \\
(*)\end{array}$ & $\begin{array}{c}\text { Belgium } \\
\left({ }^{\star \star}\right)\end{array}$ & $\begin{array}{c}\text { Other country } \\
(\star \star)\end{array}$ & $\mathrm{HI}$ & Alcohol & Drunk \\
\hline $\begin{array}{l}\text { The Crab with } \\
\text { the Golden Claws }\end{array}$ & 1941 & $20(4)$ & Belgium (1) & Morocco (19) & 24 & 11 & 6 \\
\hline $\begin{array}{l}\text { The Shooting } \\
\text { Star }\end{array}$ & 1942 & $5(0)$ & & Iceland (5) & 5 & 1 & 1 \\
\hline $\begin{array}{l}\text { The Secret of } \\
\text { the Unicorn }\end{array}$ & 1943 & $8(1)$ & Belgium (8) & & 9 & 5 & 1 \\
\hline $\begin{array}{l}\text { Red Rackham's } \\
\text { Treasure }\end{array}$ & 1944 & $12(1)$ & Belgium (5) & Caribbean (7) & 13 & 1 & 1 \\
\hline $\begin{array}{l}\text { The } 7 \text { Crystal } \\
\text { Balls }\end{array}$ & 1948 & $19(3)$ & $\begin{array}{l}\text { Belgium } \\
\text { (18) }\end{array}$ & France (1) & 22 & 1 & 1 \\
\hline Prisoners of Sun & 1949 & $24(3)$ & & Peru (24) & 27 & 2 & 1 \\
\hline $\begin{array}{l}\text { Land of Black } \\
\text { Gold }\end{array}$ & 1950 & $4(0)$ & & Khemed (4) & 4 & 0 & 0 \\
\hline Destination Moon & 1953 & $22(1)$ & & $\begin{array}{l}\text { Syldavia (21) } \\
\text { Space (1) }\end{array}$ & 23 & 0 & 0 \\
\hline $\begin{array}{l}\text { Explorers on the } \\
\text { Moon }\end{array}$ & 1954 & $19(0)$ & & $\begin{array}{l}\text { Space (11) } \\
\text { Moon (6) } \\
\text { Syldavia (2) }\end{array}$ & 19 & 5 & 3 \\
\hline $\begin{array}{l}\text { The Calculus } \\
\text { Affair }\end{array}$ & 1956 & $21(6)$ & Belgium (5) & $\begin{array}{l}\text { Switzerland } \\
(14) \\
\text { Borduria (2) }\end{array}$ & 27 & 0 & 0 \\
\hline $\begin{array}{l}\text { The Red Sea } \\
\text { Sharks }\end{array}$ & 1958 & $23(0)$ & Belgium (5) & Khemed (18) & 23 & 3 & 1 \\
\hline Tintin in Tibet & 1960 & $20(2)$ & & $\begin{array}{l}\text { India (3) } \\
\text { Nepal (3) } \\
\text { Tibet (14) }\end{array}$ & 22 & 4 & 2 \\
\hline $\begin{array}{l}\text { The Castafiore } \\
\text { Emeralds }\end{array}$ & 1963 & $10(1)$ & $\begin{array}{l}\text { Belgium } \\
\text { (10) }\end{array}$ & & 11 & 0 & 0 \\
\hline Flight 714 & 1968 & $6(1)$ & & Indonesia (6) & 7 & 0 & 0 \\
\hline $\begin{array}{l}\text { Tintin and the } \\
\text { Picaros }\end{array}$ & 1976 & $12(1)$ & Belgium (3) & $\begin{array}{l}\text { San Theodoros } \\
\text { (9) }\end{array}$ & 13 & 0 & 0 \\
\hline$N=$ & & $225(24)$ & 55 & 170 & 249 & 33 & 17 \\
\hline
\end{tabular}

(*): number of events leading to two health impairments

$(* *)$ : number of events according to the country where they occur

HI-: Health impairments-;

Alcohol-: Events occurring while Haddock had drunk;

Drunk-: Events occurring while Haddock presented with drunkenness;

$\mathrm{N}=$ overall number of events, occurring in Belgium, in a country outside Belgium, while

Haddock has drunk alcohol, and while Haddock presented with drunkenness 
Table II: Traumatic health impairments suffered by Haddock

\begin{tabular}{llr}
\hline Concussion & Concussion alone & 94 \\
& Concussion during PT & 15 \\
Grade of concussion & Grade I & $61+6$ \\
(alone + during PT) & Grade II & $30+7$ \\
& Grade III & $1+0$ \\
& Grade IV & $2+2$ \\
Total Concussion & & $\mathbf{1 0 9} \mathbf{( 5 6 \% )}$ \\
\hline BTWC & BTWC alone & 40 \\
Total BTWC & BTWc during PT + other event & $9+2$ \\
\hline Burns* & & $\mathbf{5 1} \mathbf{( 2 6 \% )}$ \\
Intoxication & & 2 \\
Animal and human bites** & & 4 \\
Insect stings*** & & 4 \\
Wounds & & 3 \\
Miscellaneous**** & & 8 \\
Total other trauma & & $\mathbf{3 3}(\mathbf{1 7 \% )}$ \\
\hline Total trauma & $\mathbf{1 9 3}$ \\
\hline
\end{tabular}

PT: Polytraumatism; all PT were associated with concussion grade I $(n=6)$, II $(n=7)$, and IV $(n=2)$ giving a total of 109 concussions; 9/15 PT were associated with BTWC.

BTWC: Body Trauma without consequences

* 10/12 burns related to Haddock's tobacco habit

** 4 bites : Snowy (1), llama (1), Miarka (1), parrot (1)

*** 4 insect stings: mosquito (3), bee (1)

**** 8 miscellaneous: hypoxemia (1), near-drowning (1), visual trouble (1), struck by lightning (1), hypothermia (1), amnesia (1), twisted ankle (1), contact dermatitis (1) 
Table III: Non-traumatic health impairments (HI) suffered by Haddock

HI related to alcohol intake

Drunkenness

Antabuse effect

Delirium Tremens

Liver cirrhosis

Sleeping trouble *

HI not related to alcohol intake

Sleeping trouble *

Medical problem **

g-force

Anxiety/depression

Miscellaneous***

TOTAL
$32(57 \%)$

21

6

2

1

2

$24(43 \%)$

5

6

4

5

4

56

* Seven cases of sleeping trouble: nightmares (3), hypersomnia (3), insomnia (1),

** Six medical problems: malaise (2), coryza, cardiac arythmia, OPH and ENT (1 each)

*** Miscellaneous: heatstroke (1), hypoxemia (1), hypnosis (1), amnesia (1) 
Table IV: 225 events leading to 249 health impairments suffered by Captain Haddock

\begin{tabular}{llr} 
Event category & Event detail & Total \\
Intentional & Haddock-related* & \\
& Friend-related & 20 \\
& Third party-related & 13 \\
& Tintin-related & 8 \\
& Homicide attempt & 2 \\
& & 2 \\
Total & & $\mathbf{4 5}$ \\
\hline Non intentional & Haddock-related* & \\
\hline & Third part and friend-related & 92 \\
& Transport-related/accidents** & 25 \\
& Environmental & 26 \\
& Tintin-related & 22 \\
& Other unintentional events & 7 \\
Total & & $\mathbf{1 8 0}$
\end{tabular}

*: Haddock-related events ( $\mathrm{n}=112$ ) includes 28 falls, 23 bumps (19 into something, four into someone), 18 alcohol-related medical events, 17 blows (by something), 15 medical problems (unrelated to alcohol), five burns, and six other events.

**: includes six falls including three falls from an animal used as a mode of transport (horses, cow), and three falls in a means of transport (plane, rocket); seven medical problems (ENT, back pain, and five NTLoC); 12 bumps or blows (car, tank, rocket, plane); one car accident 


\begin{tabular}{|l|l|l|l|l|}
\hline & Tintin & Haddock & p-value & OR (95CI)** \\
\hline Number of adventures & 23 & 15 & & \\
\hline Total number of events/HI & $236 / 244$ & $225 / 249$ & & \\
\hline $\begin{array}{l}\text { Median (quartile) number } \\
\text { of HIs per album }\end{array}$ & $8(4-15.5)$ & $19(10-23)$ & $0.03^{*}$ & - \\
\hline Trauma & $190 / 244(77 \%)$ & $193 / 249(78 \%)$ & 1 & $1.0(0.8-1.3)$ \\
\hline CC & $118 / 244(48.4 \%)$ & $109 / 249(43.7 \%)$ & 0.57 & $1.1(0.8-1.5)$ \\
\hline CCIII/IV among all the CC & $28 / 118(23.7 \%)$ & $5 / 109(4.6 \%)$ & $<0.001$ & $5.1(1.9-17.7)$ \\
\hline LoC & $46 / 244(18.9 \%)$ & $14 / 249(5.6 \%)$ & $<0.001$ & $3.3(1.8-6.8)$ \\
\hline $\begin{array}{l}\text { Proportion of HIs occurred } \\
\text { under the influence of } \\
\text { alcohol }\end{array}$ & $5 / 244(2.0 \%)$ & $38 / 249(15.3 \%)$ & $<0.001$ & $0.05-0.35$ \\
\hline
\end{tabular}

Table 5. Comparison of variables between Tintin and Captain Haddock.

HIs : Health Impairments; CC : Concussion; LoC : Loss of Consciousness

*Continuous variables compared using the Student test with $\mathrm{p}$-value significant when $\mathrm{p}<0.05$

and Odd Ratio (OR) with 95\% confidence interval (95CI)

** Categorical variables compared by using the Fisher exact test 